\author{
Urszula GOLASZEWSKA-KACZAN, PhD, Professor University of Bialystok \\ Institute of Management, University of Bialystok \\ e-mail: u.golaszewska@uwb.edu.pl \\ ORCID: 0000-0003-2084-6268
}

\author{
Ewa KUZIONKO-OCHRYMIUK, PhD \\ Institute of Management, University of Bialystok \\ e-mail: e.kuzionko-ochrymiuk@uwb.edu.pl \\ ORCID: 0000-0003-3172-5998
}

DOI: $10.15290 /$ oes.2020.01.99.11

\title{
UNIVERSITY YOUTH AND ETHICAL PURCHASES ${ }^{1}$
}

\begin{abstract}
Summary
Purpose - The goal of this paper was to present the views, opinions and attitudes of university students on the topic of ethical shopping. It was based on theoretical considerations concerning the characteristics of a modern customer and ethical consumption.

Research method - The study was conducted on a group of students from the Faculty of Economics and Management at the University of Bialystok. A survey was used in order to gather information. It consisted of 12 questions, including 7 questions in the content-related part with 5 questions concerning the specifics of the respondents' examined. The latter section included characteristics such as their field of studies, gender, employment status, the amount of income a respondent can dedicate to shopping activities (after paying fixed expenses). The selection of the personal characteristics was not a random process. It was hypothesised that those characteristics could differentiate the students' approach to ethical consumption.

Results - It was established that the amount of money a student can devote to shopping did not have any significant influence on the survey responses. It seems necessary to conduct further research in order to provide more comprehensive information on the actual attitude of respondents, as well as on the impact of education on changes in the students attitudes to ethical consumption and shopping. Also, further analysis of other details of the respondents may be beneficial for deeper findings.

Implications /originality / value - The paper provides interesting information about the academic youths' attitude to ethical consumption. It also encourages further in-depth research.
\end{abstract}

Keywords: ethical consumption, modern customer, ethical customer

JEL Classification: A13, M30, M39

1 Article received on 01 July 2019, accepted on 2 December 2019. 


\section{Introduction}

It is a cliché to say that no company may function without its clients. Companies create their products for their clients and, in turn, clients build organizational success. However, clients are just one element of a companies' environment, which - as all its other components - undergoes continuous change. Clients' transformations influence their role in the market relations.

Sensitivity to ethical issues has become one of the key characteristics of modern buyers. They start paying attention both to the reputation ${ }^{2}$ of the company whose product they purchase, as well as to the ethical aspects of the product offering itself. Additionally, modern customers also change their approach to consumption itself.

The goal of this paper was to present opinions and declared attitudes of university youth concerning ethical shopping, against the background of theoretical considerations concerning the characteristics of modern-day clients and ethical consumption. The study was conducted using a group of students from the Faculty of Economics and Management at the University of Bialystok. A survey method was utilized to gather information. It was hypothesised that the dedicated amount of income to be spent has an impact on the opinions and declarations of students concerning the issue of ethical consumption.

\section{Modern-day customers}

Parallel to the development of the purchasing culture, there is also a change in the profile of a typical consumer. Nowadays, customers are increasingly demanding, or it may even be stated that they have become shopping specialists. They have quickly adjusted to the changing reality, as well as to the new innovative and mobile solutions. They make frequent use of modern technologies to facilitate their lives, take reasonable and fast purchasing decisions which frequently have to be made in haste. The characteristics of a modern-day customer include [Sztucki, 2001, p. 128]:

- free choice and purchase of all types of products from various manufacturers or trading and service companies at various times and in numerous places,

- higher level of education and experience thanks to contacts with the world,

- considerable diversification of needs and possibilities to satisfy them with a variety of domestic or foreign products of differentiated prices and quality,

- focused on health food, health protection, attractive appearance and youth,

- clear distinction of different groups of needs and types of products addressed to young and entrepreneurial people,

- $\quad$ higher and constantly increasing level of requirements concerning the range of products and/or service quality,

\footnotetext{
2 According to Bennett and Rentschler [2003], a corporate reputation refers to the value judgment about an organisation formed over a long period, regarding its consistency, trustworthiness and reliability.
} 
- higher and diversified income, which influences the needs and demand to satisfy them,

- $\quad$ readiness to accept new products which are useful, attractive and original,

- willingness to purchase popular products of global brands and reputation, criticism towards advertising, as well as attempts of sales manipulation,

- treating shopping as a pleasant leisure activity and expectation of related values.

The modern consumer is frequently referred to as a new-era consumer and a well-informed consumer. Such consumers are independent. Modern customers search for information, underline their individuality as well as authenticity. They get involved in market processes and will collect, analyse and select information carefully. Such customers are also aware of their rights and they behave ethically [Włodarczyk-Śpiewak, 2011, p. 143].

The above characteristics change the role of a customer in the marketplace. Table 1 presents the transformation of the customer's role in market relations. Its today's society it is assumed that a customer is an active subject, an actor playing a major role in the game of competition.

TABLE 1

Customers' roles in competition

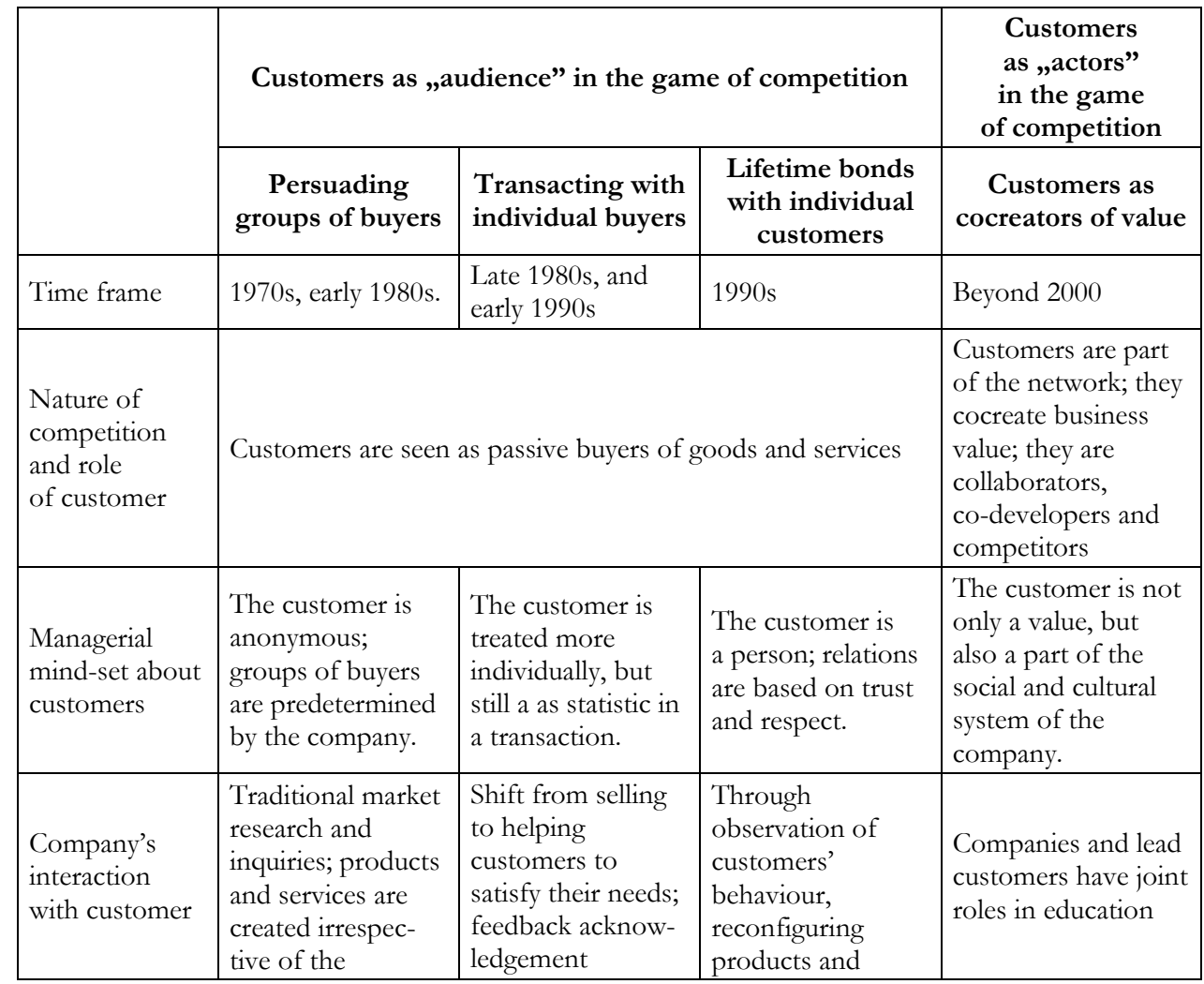




\begin{tabular}{|c|c|c|c|c|}
\hline & \multicolumn{3}{|c|}{ Customers as „audience” in the game of competition } & \multirow{2}{*}{$\begin{array}{c}\text { Customers } \\
\text { as ,actors” } \\
\text { in the game } \\
\text { of competition }\end{array}$} \\
\hline & $\begin{array}{c}\text { Persuading } \\
\text { groups of buyers }\end{array}$ & $\begin{array}{l}\text { Transacting with } \\
\text { individual buyers }\end{array}$ & $\begin{array}{c}\text { Lifetime bonds } \\
\text { with individual } \\
\text { customers }\end{array}$ & \\
\hline \multirow[t]{2}{*}{ Time frame } & 1970s, early 1980s. & $\begin{array}{l}\text { Late 1980s, and } \\
\text { early 1990s }\end{array}$ & $1990 \mathrm{~s}$ & Beyond 2000 \\
\hline & feedback & & $\begin{array}{l}\text { services based on } \\
\text { deep understan- } \\
\text { ding of customers }\end{array}$ & \\
\hline $\begin{array}{l}\text { Purpose and } \\
\text { flow of } \\
\text { communication }\end{array}$ & $\begin{array}{l}\text { One-way } \\
\text { communication }\end{array}$ & $\begin{array}{l}\text { Database marke- } \\
\text { ting; two-way } \\
\text { communication }\end{array}$ & $\begin{array}{l}\text { Relationship mar- } \\
\text { keting' two-way } \\
\text { communication }\end{array}$ & $\begin{array}{l}\text { Active dialogue with } \\
\text { customers }\end{array}$ \\
\hline
\end{tabular}

Source: [Prahalad, Ramaswamy, 2000a, p. 40; Prahalad, Ramaswamy, 2000b, p. 79].

Consumers who are more aware of their needs and who play an active role on the market, frequently also adopt new consumer's values. That is the foundation for ethical consumption.

\section{Ethical consumption}

When we want to define ethical consumption, it should be stated that there is no single, generally adopted definition of such consumption.

In the published subject literature, it is possible to identify a wider and a narrower definition of ethical consumption. The narrow approach stresses the importance of factors determining the ethical behaviour of consumers. Haanpää states that ethical consumption includes three major factors [Niinimaäki, 2010, p. 152]:

- contextual factors (economic, cultural and social resources, also normative factors),

- individual factors (e.g. gender, age, economic status, circumstantial factors such as sales, bargains, also routines and habits),

- personality factors (values, beliefs, mindset, attitudes, needs, intentions).

In the broader understanding, ethical consumption is defined as a set of moral principles and standards that guide the behaviour of individuals or groups as they obtain, use and dispose of goods and services [Muncy, Vitell, 1992, p. 298]. In that dimension it is stressed that ethical values should be applied at the moment of taking consumer decisions [Crane, Matten, 2004, p. 290].

Moving further from this definition, Crane and Matten clearly state that ethical consumption may signify a conscious rejection, for example, of certain products due to their harmfulness for the natural environment or a negative approach of a specific company to the issue of global warming. Many scholars dealing with the issue of ethical consumption point to the fact that ethical consumers do not reject consumption as such, but they rather choose products which express their ethical and social attitudes [Szmigin et. al., 2007, p. 399]. On the other hand, Manchiraju 
and Sadachar [2014, p. 357] stress that ethical consumption can be characterised with a positive ethical behaviour expressed with purchasing fair trade products or products which are environment-friendly, or it may be related to avoiding or boycotting unethical products or companies operating in a unethical way. The Authors of this article assumed that ethical consumption means acknowledging information concerning the ethical aspect of a product or a company offering such a product, in the process of making consumer decisions.

Ethical consumption is also referred to as responsible consumption or sustainable consumption [Neale, 2015, pp. 145-146].

The analysis of literature relating to ethical consumption allows us to distinguish three major areas of considerations concerning such consumption:

- consumers' attitudes towards products including an ethical element, such as respecting human rights during the production process [Long, Murrey, 2013, pp. 351-375],

- consumers' practices based on ethical values, including ecological behaviour, purchasing fair trade products [Andorfer, 2013, pp. 424-443],

- political aspect of consumption manifested in the implementation of political goals in everyday consumption. This area relates to the diversity of organisational forms acting for consumers which include: ethical trade organisations, organisations promoting fair trade, cooperative movements, campaigns boycotting unethical companies or products [Pepper et. al, 2009, s. 126-136].

Further research will be focused on the consumers' declared attitudes towards ethical shopping.

Ethical consumers take into consideration ethical values when making purchasing decisions; it means that they are aware of ethical consequences of their consumer practices. Such conscious behaviour of consumers is the manifestation of their ethical convictions and values, as well as presentation of themselves as ethical consumers. It may be assumed that the notion of ethical consumption refers to consumers who represent the desired consumption behaviour on the market.

For the needs of this study it was assumed that the fundamental ethical principles of consumption can be classified as the following behaviour [www 1]:

- limiting consumption - Ethical shopping is not enough. It is also necessary to reduce the volume of products which we purchase, consume and dump. Before going shopping, a consumer should answer the questions: "Do I really need this product?" and "What is going to happen with this product when it is not needed anymore?",

- shopping near the place of living - Local shopping results in reduced volumes of exhausts released into the air, and also support for the local community; at the same time, it supports local shops which find it increasingly challenging to stay on the market,

- $\quad$ ethical saving and investing - It is important not only how we spend money but also at which institution or a bank we keep our money, and where and in what way we invest our funds, 
- $\quad$ purchasing used or recycled products - A product which we purchase does not always need to be new. Recycled or second-hand products prevent waste of precious resources and help to reduce the stacks of garbage deposited on landfills.

Ethical consumption may be also analysed with respect to ethical shopping behaviour [Tallontire et. al., 2001, pp. 10-14], which means taking into considerations the motivation of consumers purchasing specific goods. When we buy organic food, we not only support the environmental protection, but we also protect our health, as well as health of people working for its production. When we buy fair trade products, we express our recommendation for the environment protection, but also respect for human rights and dignity, as well as workers' rights.

For the needs of this study, it was assumed that within ethical shopping consumers may take decisions concerning [www 2]:

- the choice of specific product categories - it means the selection of specific products which, in our opinion, are ethical,

- the avoidance of specific product categories - it is a 'negative selection', which means avoiding to purchase products to which we have a negative attitude,

- the focus on specific companies - such approach to shopping means a general approach to operations of specific companies. Avoidance of purchasing products of companies who in their operations violate specific ethical standards and choosing companies who are not only profit-driven but who also respect ethical values and are environment-friendly,

- general approach - it means the assessment of a company and its products with respect to following principles of human rights, environment protection, etc, and selection of such products which to the greatest degree meet the defined ethical criteria.

It is worth emphasizing that for the development of ethical consumption, among other things, it is necessary to provide a highly developed information function of marketing. It is necessary to create a situation when advertising provides reliable information about the product and its manufacturer, since any attempt to manipulate consumers shall lead to a boycott of products supplied by a specific company. In such a society, the consumer is a party who has a strong influence on the market situation and has powerful bargaining power [Kołodko, 2008, s. 140].

\section{Study results}

To identify the opinions and declarations of university youth with respect to ethical consumption, a study was conducted through the use of a survey questionnaire. The questionnaire, after it was verified post the preliminary study ${ }^{3}$, comprised 12 questions including 7 content-related questions and 5 questions concerning

\footnotetext{
${ }^{3}$ After conducting a pilot study on the group of 30 respondent, two questions in the questionnaire were rephrased and the PLN amount thresholds were redefined.
} 
particulars of the respondents. Respondents' details included such characteristics as: field of studies, gender, employment status, the amount of money a respondent can dedicate for shopping (after paying fixed expenses). The selection of those features was not random. It was assumed that such characteristics may differentiate the approach of students to ethical consumption.

An appropriate study was planned in a number of stages. The goal of the first stage was to gather general information concerning the attitude of academic youth to ethical consumption. Two sub-stages were identified in this stage. In the first substage, the study group of respondents included the first -year students of the first level studies. In the second sub-stage, the study group of respondents is going to include the second-year students of the second level studies (to compare opinions of students starting and ending their university education). The second stage of the study is going to include a thorough analysis of selected elements of ethical consumption.

Results presented in this paper are the outcome of research conducted within the first sub-stage of the study. The study group included 106 students of the Faculty of Economics and Management at the University of Bialystok. Respondents were randomly selected from all regular first year students of the first level studies of: economics and law, management, economy, international business relations. The number of students in the groups included in the study was comparable and amounted to:

- $\quad$ economics and law (EP) -25 students $(23.6 \%)$,

- economy -26 students $(24.5 \%)$,

- $\quad$ management -29 students $(27.4 \%)$,

- $\quad$ international business relations (MSG) - 26 students (24.5\%).

Other information concerning respondents is presented in table 2 .

Due to its limited scope, this article presents only the study results with respect to one feature defined in the respondents' particulars which is the amount of money a respondent can allocate for the purposes of shopping. The respondents were informed that it should be the available budget after paying monthly expenses (such as rent or electricity bills). The Authors are fully aware that the results of this study cannot be generalised as describing all university youth. This research is only a case study with reference to the students of the Faculty of Economics and Management at the University of Bialystok.

The goal of the first two questions was to obtain information as to how students understand two basic categories related to the subject.

In the first question which was multiple choice, students were asked to indicate the most important principles of ethical consumption in their opinion. Chart 1 presents the percentage of indications scored by individual principles of ethical consumption. 
TABLE 2

Information concerning respondents

\begin{tabular}{|l|c|c|c|c|c|c|c|c|c|c|}
\hline & Total & \% & EP & \% & $\begin{array}{c}\text { Eco- } \\
\text { nomy }\end{array}$ & $\mathbf{\%}$ & $\begin{array}{c}\text { Mana- } \\
\text { gement }\end{array}$ & \% & MSG & \% \\
\hline Including & 106 & & 25 & & 26 & & 29 & & 26 & \\
\hline Women & 77 & 72.6 & 19 & 76 & 24 & 92.3 & 16 & 55.2 & 18 & 69.2 \\
\hline Men & 29 & 27.4 & 6 & 24 & 2 & 7.7 & 13 & 44.8 & 8 & 30.8 \\
\hline Employed & 31 & 29.2 & 8 & 32 & 7 & 26.9 & 9 & 31 & 7 & 26.9 \\
\hline Unemployed & 75 & 70.8 & 17 & 68 & 19 & 73.1 & 20 & 69 & 19 & 73.1 \\
\hline $\begin{array}{l}\text { Respondents } \\
\text { who can dedicate } \\
\text { max. PLN 200 } \\
\text { for shopping }\end{array}$ & 14 & 13.2 & 2 & 8 & 2 & 7.7 & 4 & 13.8 & 6 & 23.1 \\
\hline $\begin{array}{l}\text { Respondents who } \\
\text { can dedicate max. } \\
\begin{array}{l}\text { PLN (201 - 500> } \\
\text { for shopping }\end{array}\end{array}$ & 62 & 58.5 & 14 & 56 & 21 & 80.8 & 17 & 58.6 & 10 & 38.5 \\
\hline $\begin{array}{l}\text { Respondents who } \\
\text { can dedicate max. } \\
\begin{array}{l}\text { PLN (501 - 800> } \\
\text { for shopping }\end{array}\end{array}$ & 29 & 27.4 & 8 & 32 & 3 & 11.5 & 8 & 27.6 & 10 & 38.5 \\
\hline $\begin{array}{l}\text { Respondents who } \\
\text { can dedicate more } \\
\text { than PLN 800 for } \\
\text { shopping }\end{array}$ & 1 & 0.9 & 1 & 4 & none & none & none & None & none & none \\
\hline
\end{tabular}

Source: authors' own compilation according to the conducted research.

Students who participated in the study indicated the limited consumption by smaller and less frequent shopping as the main principle of ethical consumption (chart 1). This principle was indicated by $87.7 \%$ of respondents. This group included 13 students $(13.9 \%)$, who indicated concurrently the principle of buying recycled products and 1 student who indicated the principle of ethical savings and investing. In total, $19.8 \%$ of respondent indicated buying recycled products, $5.7 \%$ of respondents indicated ethical saving and investing, and $0.09 \%$ of respondents indicated shopping close to the place of residence. 
CHART 1

Percentage of respondents indications to the question concerning ethical consumption (distribution of answers with reference to the declared income)

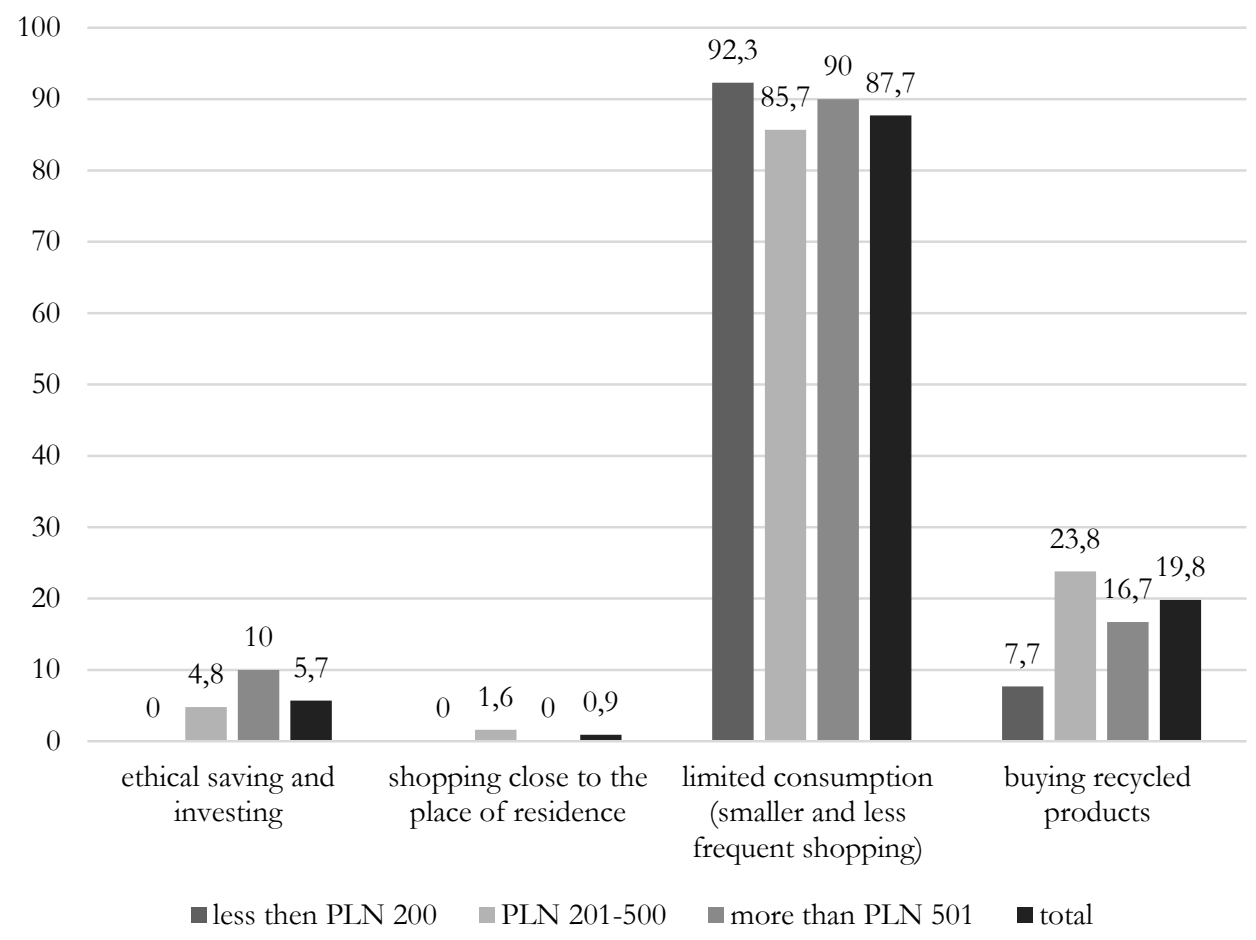

Source: authors' own compilation according to the conducted research.

According to the results, it may be concluded that the budget available for shopping did not have a considerable impact on the selection of the most ethical principle of ethical consumption, that is the limitation of consumption. There are some differences concerning the remaining principles. What is interesting is that the group of students with the lowest amount available for shopping were the smallest group to indicate buying recycled products. On the other hand, the largest group to indicate the principle of ethical saving and investing were the students with an amount above PLN 501 available for shopping, a fact which is quite justified since they are people with the largest available amounts of financial resources.

In the second question, respondents were asked to explain what the manifestations of ethical shopping are. The results are presented on chart 2 . 
CHART 2
Percentage of respondents indications to questions concerning manifestations of ethical shopping (answers' distribution according to the declared income)

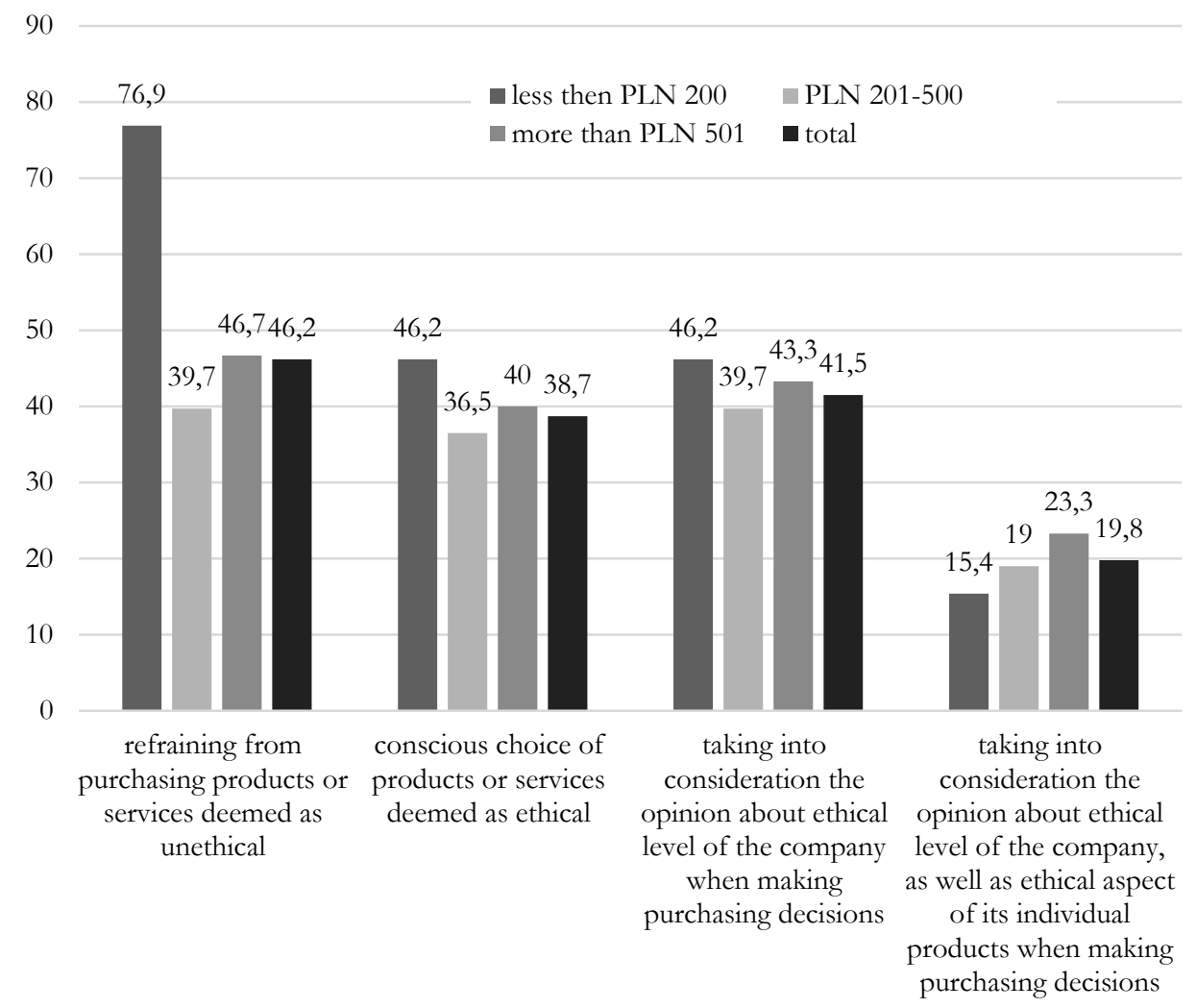

Source: authors' own compilation according to the conducted research.

In the case of this question, the respondents answers were not so clear-cut. The students' answers were divided into groups with respect to their opinion on the manifestation of ethical shopping. The smallest number of indications was scored by the "general approach", i.e. taking into consideration both the opinion about the company, and its products; that was the response of $19.8 \%$ of respondents. This answer was indicated mainly by people with the highest disposable income available for shopping purposes. With respect to negative selection, i.e. refraining from purchasing products or services deemed as unethical (this answer scored the highest number of indications, i.e. $46.2 \%$ ) it can be clearly seen that it was mainly indicated by the group of students with the lowest available amount for shopping (corresponding to $76.9 \%$ ). 
In the question relating to the evidence of ethical shopping, there were references to „ethical company” and „ethical product”. Therefore, it was necessary to clarify what is the respondents' understanding of these two terms. The students' answers are presented in charts 3 and 4 .

\section{Percentage of respondents indications to the question concerning the understanding of the term of an ethical company (answers' distribution according to the declared income)}

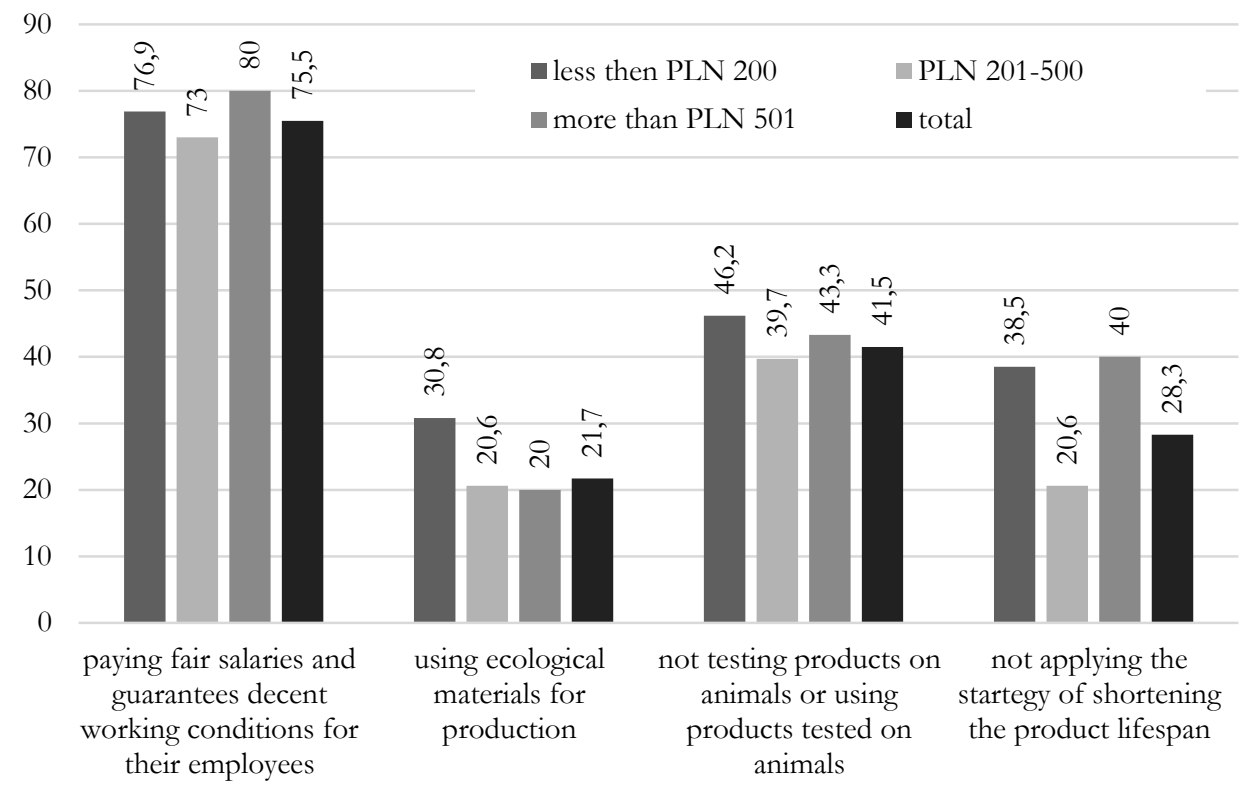

Source: authors' own compilation according to the conducted research.

From the collected results, it transpires that students identify an ethical company mainly with organisations who pay fair salaries and guarantee decent working conditions for their employees. This response was indicated by a $75.5 \%$ of respondents. The second answer with the highest score defined an ethical company as one which does not test its products on animals and does not use products tested on animals. This answer was indicated by $41.5 \%$ of respondents. In both cases, the declared amount available for shopping did not differentiate significantly the popularity of those answers. However, respondent with a budget available for shopping ranging from PLN 201 to 500 paid the least attention to the fact of not applying by the company the strategy of shortening the product lifespan, and students with the lowest amount available for shopping were the main group who indicated the factor of using ecological materials for production. 
Answers concerning the understanding of an ethical product show that according to the respondents it is difficult to indicate one dominating quality of such a product. The results are presented on chart 4 .

\section{CHART 4}

\section{Percentage of respondents indications to the question concerning the understanding of the term of an ethical product (answers' distribution according to the declared income)}

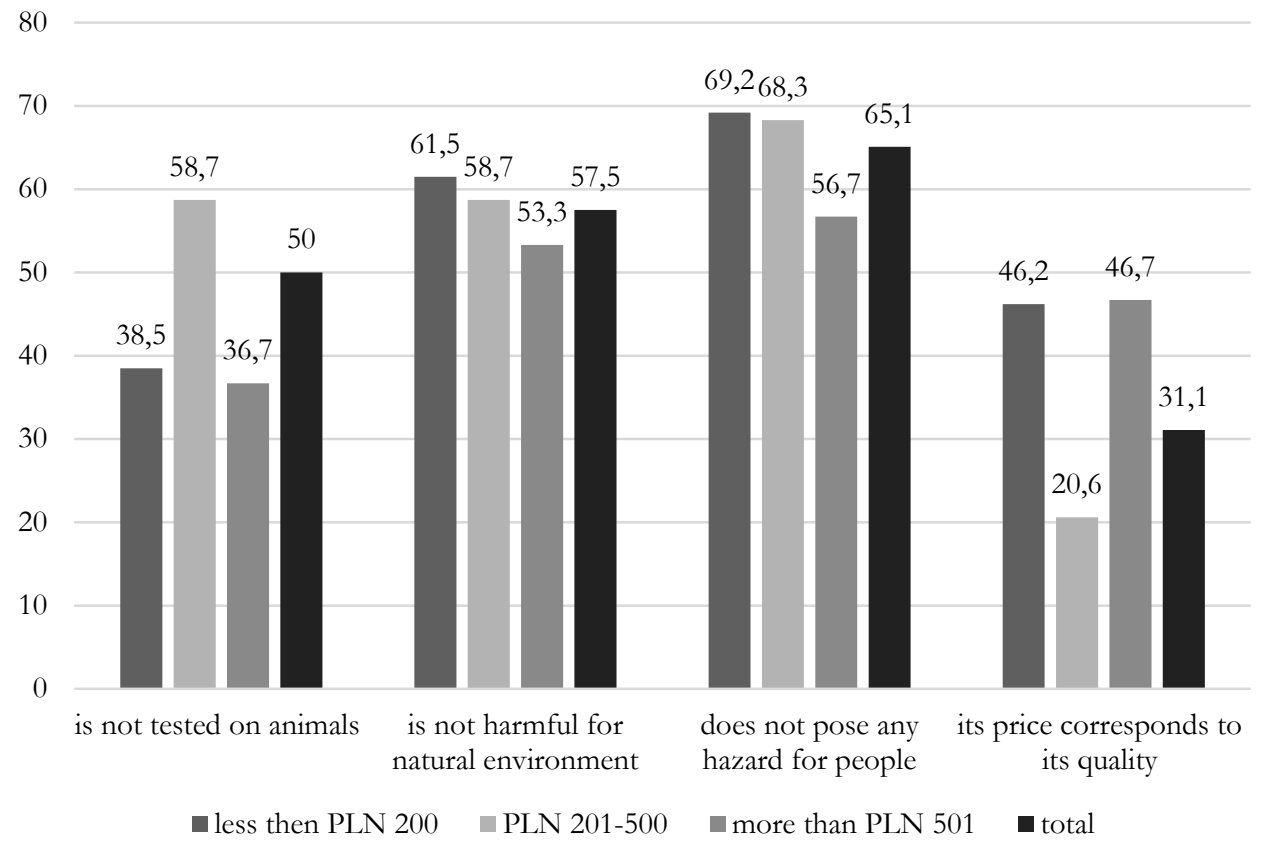

Source: authors' own compilation according to the conducted research.

According to the respondents, an ethical product does not pose any hazard for people (quality indicated by $65.1 \%$ ), is not harmful for the natural environment $(57.5 \%)$ and is not tested on animals $(50 \%)$. In the case of the first two qualities, the level of declared amount available for shopping does not differentiate in a significant way the popularity of those answers. Sensitivity to animal suffering was indicated mainly by students with a budget ranging from PLN 201 to 500 available for shopping. On the other hand, 31.1\% of all students indicated that a product where price corresponds to quality is an ethical product. In this group of respondents, the most numerous were those students who can afford to spend more than PLN 501 for shopping per month, i.e. 46.7\%.

After learning about the students' opinion on ethical consumption and ethical products, and also after diagnosing the respondents' understanding of the terms „ethical product” and „ethical company”, the question concerning their shopping 
behaviour was asked to confront theory with practice. First, the respondents were asked to indicate the form of ethical shopping which they use themselves. These results are presented on chart 5 .

\section{Percentage of respondents indications to questions concerning their preferred form of ethical shopping (answers' distribution according to the declared income)}

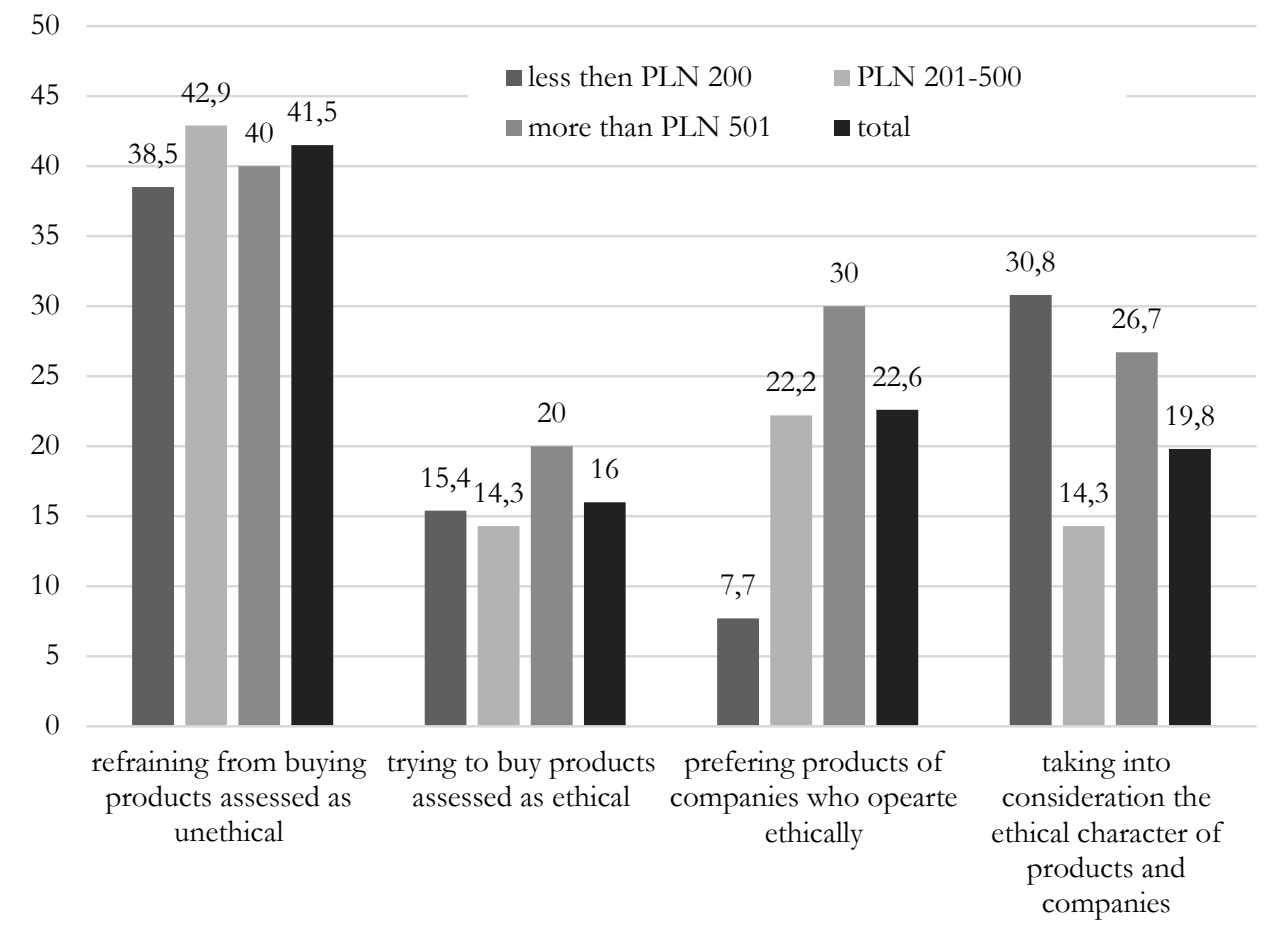

Source: authors' own compilation according to the conducted research.

It turned out that students most frequently refrain from buying products which they assess as unethical $(41.5 \%)$. The largest number of respondents who indicated this answer have the budget ranging from PLN 201 to 500 to spend monthly for shopping $(42.9 \%)$. A significantly smaller group of respondents answered that they chose products from companies who operate in an ethical way $(22.6 \%)$. In this group, the most answers were indicated by students with an available monthly budget for shopping above PLN 501. Students who take into consideration the ethical character of products and companies constituted 19.8\% of all respondents (with the majority of those who can monthly spend less than PLN 200 for shopping, i.e. $30.8 \%$ ). $16 \%$ of respondents try to buy products which they believe to be ethical. The majority of this group can spend more than PLN 501 for shopping monthly 
$(20 \%)$. It is optimistic that the majority of students (more than $80 \%$ ) declare that they use some form of ethical shopping.

To deepen our knowledge on ethical shopping, respondents were asked to define which product groups are subject to ethical shopping in their cases. The results are presented on chart 6 .

CHART 6

\section{Percentage of respondents indications to questions concerning products which are most often subject to ethical shopping (answers' distribution according to the declared income)}

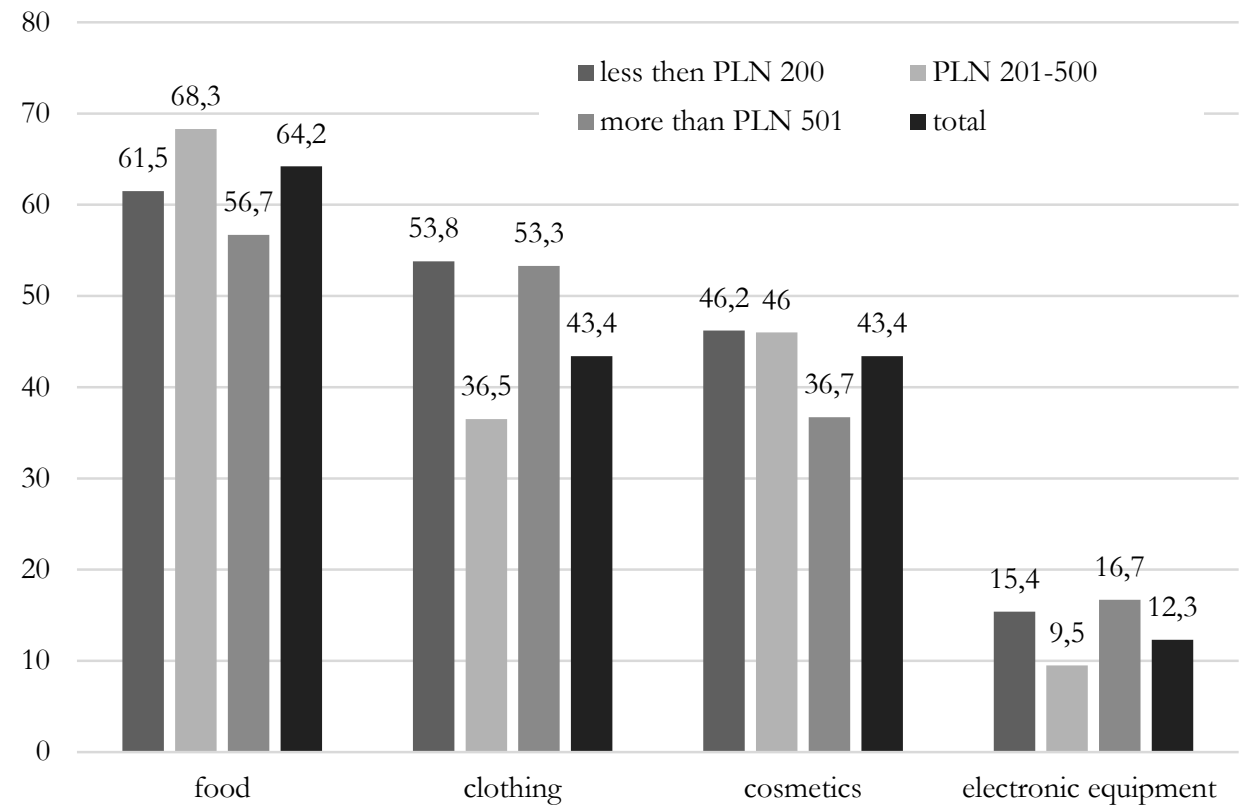

Source: authors' own compilation according to the conducted research.

Food turned out to be the group of products which respondents presented with the highest ethical sensitivity (chart 6). However, students with the highest shopping budget seem to pay the least attention to the ethical aspect of their shopping in this respect. $43.4 \%$ of students perform ethical shopping with respect to both cosmetics and clothing purchases. The lowest interest in the ethical purchase of cosmetics was presented by respondents whose declared budget for shopping is above PLN 501, and with respect to clothes - students with the budget available for shopping ranging from PLN 201 to 500 per month. It is worthwhile noting that $38.2 \%$ of respondents who declared ethical shopping in the area of food also declared ethical approach to the purchase of clothing, and $30.9 \%$ also to the purchase of cosmetics. The smallest number of respondents, i.e. $12.3 \%$, pay attention to the ethical aspect of shopping in the case of purchasing electronic equipment. Such an answer was 
given in the majority by people with a monthly budget for shopping that exceeded PLN 501 (16.7\%).

It should be stressed that all respondents declared at least one group of products in case of which they chose the ethical approach.

Finally, respondents were asked to indicate the most important reasons in their opinion, which may be an obstacle to the practice of ethical shopping. The results are presented in chart 7.

CHART 7

Percentage of respondents indications concerning obstacles for ethical shopping (answers' distribution according to the declared income)

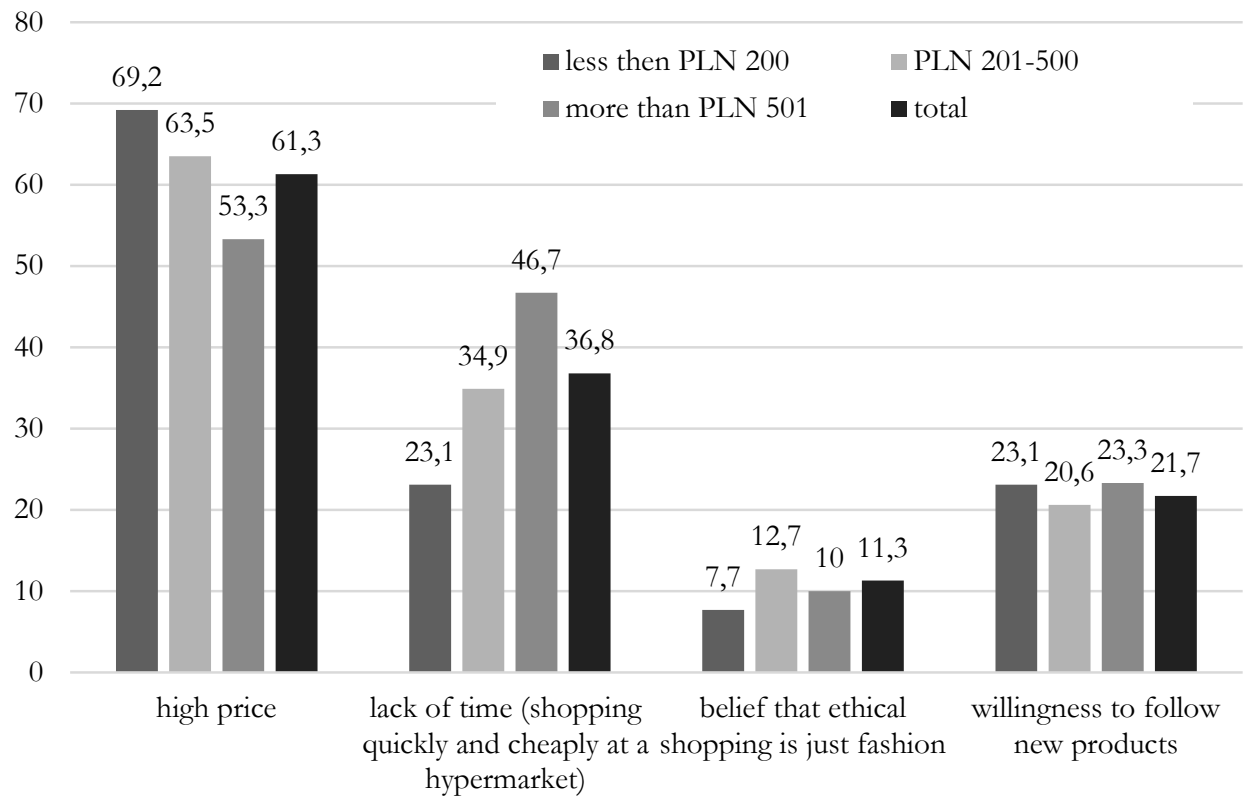

Source: authors' own compilation according to the conducted research.

According to the respondents, the main factor limiting ethical shopping is the high price of products considered to be ethical. This is an obstacle for $61.3 \%$ of respondents, mainly for students with the lowest shopping budget. At the same time, $27.7 \%$ of respondents, for whom the high price is an obstacle for ethical shopping, indicated the lack of time as a barrier for such shopping. Ethical shopping requires consideration, obtaining information, frequently it is necessary to spend time at the stage of making a shopping decision, and also during shopping. In total, lack of time as a limitation was declared by $36.8 \%$ of students. The majority of this group were respondents who possessed the highest shopping budget.

A visibly smaller group of respondents $(21.7 \%)$ declared that an obstacle may be the desire to follow all new products on the market (that is a situation when the 
desire to own new products is stronger that reason or the actual need to own such a product). According to $11.3 \%$ of respondents, the limitation is the conviction that ethical shopping is only a fashion.

To define the interdependence between the approach to ethical consumption and ethical shopping, and the budget which the respondents can monthly spend for shopping, Pearson's chi-squared test of goodness of fit was applied, which is presented in table 3.

In the case of sociological studies, the level of significance of the Pearson's chisquared test has been used. Results can be interpreted as significant when the significance level for the specific test is smaller than 0.05 and it is insignificant in all other cases.

TABLE 3

\section{Chi-squared test results}

\begin{tabular}{|c|c|c|c|c|}
\hline \multicolumn{5}{|c|}{ The most important principle of ethical consumption } \\
\hline & $\begin{array}{l}\text { ethical saving } \\
\text { and investing }\end{array}$ & $\begin{array}{l}\text { shopping close } \\
\text { to the place } \\
\text { of residence }\end{array}$ & \begin{tabular}{|c|} 
limiting \\
consumption \\
(smaller and less \\
frequent \\
shopping) \\
\end{tabular} & $\begin{array}{c}\text { buying } \\
\text { second-hand } \\
\text { and recycled } \\
\text { products }\end{array}$ \\
\hline $\begin{array}{l}\text { Pearson's chi-squa- } \\
\text { red test results }\end{array}$ & .380 & .709 & .728 & .364 \\
\hline \multicolumn{5}{|c|}{ The evidence of ethical shopping } \\
\hline & $\begin{array}{l}\text { refraining from } \\
\text { purchasing } \\
\text { products or } \\
\text { services which } \\
\text { respondents } \\
\text { consider as } \\
\text { unethical }\end{array}$ & $\begin{array}{l}\text { conscious choice } \\
\text { of products and } \\
\text { services which } \\
\text { respondents } \\
\text { consider ethical }\end{array}$ & $\begin{array}{l}\text { taking into } \\
\text { consideration } \\
\text { opinions about the } \\
\text { ethical level of the } \\
\text { company upon } \\
\text { making purchasing } \\
\text { decisions }\end{array}$ & $\begin{array}{l}\text { taking into } \\
\text { consideration } \\
\text { opinions about } \\
\text { both the ethical } \\
\text { level of the } \\
\text { company, as well } \\
\text { as the ethical } \\
\text { aspect of } \\
\text { individual } \\
\text { products of the } \\
\text { company upon } \\
\text { making } \\
\text { purchasing } \\
\text { decisions }\end{array}$ \\
\hline $\begin{array}{l}\text { Pearson's chi-squa- } \\
\text { red test results }\end{array}$ & .049 & .797 & .886 & .812 \\
\hline \multicolumn{5}{|c|}{ An ethical company is a company which } \\
\hline & $\begin{array}{l}\text { pays fair salaries } \\
\text { and its employees } \\
\text { have decent } \\
\text { conditions of work }\end{array}$ & $\begin{array}{l}\text { uses ecological } \\
\text { materials for } \\
\text { production }\end{array}$ & $\begin{array}{l}\text { does not test } \\
\text { products on } \\
\text { animals and does } \\
\text { not use products } \\
\text { tested on animals }\end{array}$ & $\begin{array}{l}\text { does not apply the } \\
\text { strategy of } \\
\text { shortening the } \\
\text { product lifespan }\end{array}$ \\
\hline $\begin{array}{l}\text { Pearson's chi-squa- } \\
\text { red test results }\end{array}$ & .759 & .697 & .886 & .105 \\
\hline
\end{tabular}




\begin{tabular}{|c|c|c|c|c|}
\hline \multicolumn{5}{|c|}{ The most important principle of ethical consumption } \\
\hline & $\begin{array}{l}\text { ethical saving } \\
\text { and investing }\end{array}$ & $\begin{array}{l}\text { shopping close } \\
\text { to the place } \\
\text { of residence }\end{array}$ & $\begin{array}{c}\text { limiting } \\
\text { consumption } \\
\text { (smaller and less } \\
\text { frequent } \\
\text { shopping) }\end{array}$ & $\begin{array}{c}\text { buying } \\
\text { second-hand } \\
\text { and recycled } \\
\text { products }\end{array}$ \\
\hline \multicolumn{5}{|c|}{ An ethical product is a product which } \\
\hline & $\begin{array}{l}\text { is not tested on } \\
\text { animals }\end{array}$ & $\begin{array}{l}\text { is not hazardous } \\
\text { for the natural } \\
\text { environment }\end{array}$ & $\begin{array}{l}\text { does not pose a } \\
\text { risk for human life }\end{array}$ & $\begin{array}{l}\text { price is adequate } \\
\text { to its quality }\end{array}$ \\
\hline $\begin{array}{l}\text { Pearson's chi-squa- } \\
\text { red test results }\end{array}$ & .093 & .844 & .519 & .018 \\
\hline \multicolumn{5}{|c|}{ Which form of ethical consumption you choose } \\
\hline & $\begin{array}{l}\text { I try to assess the } \\
\text { products from the } \\
\text { ethical point of } \\
\text { view }\end{array}$ & $\begin{array}{l}\text { I refrain from } \\
\text { buying products } \\
\text { which I assess as } \\
\text { unethical }\end{array}$ & $\begin{array}{l}\text { I prefer products } \\
\text { of companies } \\
\text { which operate in an } \\
\text { ethical way }\end{array}$ & $\begin{array}{l}\text { I take into } \\
\text { consideration the } \\
\text { ethical character } \\
\text { of products and } \\
\text { companies }\end{array}$ \\
\hline $\begin{array}{l}\text { Pearson's chi-squa- } \\
\text { red test results }\end{array}$ & .780 & .939 & .274 & .214 \\
\hline \multicolumn{5}{|c|}{ Products which are most often subject to ethical shopping } \\
\hline & Food & Clothing & cosmetics & $\begin{array}{l}\text { electronic } \\
\text { equipment }\end{array}$ \\
\hline $\begin{array}{l}\text { Pearson's chi-squa- } \\
\text { red test results }\end{array}$ & .541 & .223 & .680 & .578 \\
\hline \multicolumn{5}{|c|}{ Limitations of ethical shopping } \\
\hline & high price & $\begin{array}{l}\text { lack of time (I } \\
\text { can do shopping } \\
\text { cheaply and } \\
\text { quickly at a } \\
\text { hypermarket) }\end{array}$ & $\begin{array}{l}\text { conviction that } \\
\text { ethical shopping is } \\
\text { just a fashion }\end{array}$ & $\begin{array}{l}\text { desire to follow all } \\
\text { new products on } \\
\text { the market }\end{array}$ \\
\hline $\begin{array}{l}\text { Pearson's chi-squa- } \\
\text { red test results }\end{array}$ & .529 & .301 & .843 & .949 \\
\hline
\end{tabular}

Source: authors' own compilation according to the conducted research.

The data presented in table 3 shows significant statistical differences only in two cases among all of the declared answers. Refraining from purchasing products or services, which we consider to be unethical products / services is the highest in the group of respondents with the lowest income, which means that the lower budget for shopping students have, to the higher degree they refrain from unethical purchasing of products or services. With respect to ethical products, respondents with a budget below PLN 200 and above PLN 501, indicated the answer about the adequacy of price to the quality the least frequent. It may be explained that people with a lower budget pay attention to the price of a product or service, and people who have a higher budget pay attention to the quality of the purchased product or a service. In other cases, the declared shopping budget did not have any impact on the respondents' answers. 


\section{Conclusions}

The conducted study provided information on the approach of students from the Faculty of Economics and Management at the University of Bialystok to the issue of ethical consumption. The study showed that university youth pay attention to the ethical aspects when making shopping decisions. Obviously, the authors of the study are fully aware that answers provided by the students should be interpreted as their declarations, and not as actual attitudes. At the same time, it should be stated that the study included only students of the first year of the Faculty of Economics and Management at the University of Bialystok. It might have had an impact on their attitude to the problem. As it was mentioned in the introduction, it seems that further study is required with the goal to both deepen information concerning the actual attitudes of respondents, as well as the impact of the education process on the change of the students attitude to ethical consumption and ethical shopping.

Additionally, the paper presents the analysis of results from the point of view of only one characteristics of respondents, i.e. the amount which they designate for shopping. It turned out that this amount does not have any significant impact on the respondents' answers. Therefore, it also seems necessary to conduct further analysis with respect to other characteristics defined in the respondents.

\section{References}

Andorfer V.A., 2013, Ethical Consumption in Germany: A Cross-Sectional Analysis of Determinants of Fair Trade Consumption (2000-2010), "Journal of Sociology", vol. 42(5), pp. 424-443.

Bennett R., Rentschler R., 2003, Foreward by The Guest Editors, "Corporate Reputation Review”, vol. 6, iss. 3, pp. 207-211, DOI: 10.1057/palgrave.crr.1540200.

Crane A., Matten D., 2004, Business Ethics: a European Perspective: Managing Corporate Citizenship and Sustainability in the Age of Globalization, Oxford University Press, Oxford.

Kołodko G.W., 2008, Wędrujacy świat, Prószyński i S-ka S.A, Warszawa.

Long M.A., Murrey D. L., 2013, Ethical Consumption, Values Convergence/ Divergence and Community Development, "Journal of Agricultural and Environmental Ethics", vol. 26(2), pp. 351-373, DOI: 10.1007/s10806-012-9384-0.

Manchiraju S., Sadachar A., 2014, Personal values and ethical fashion consumption, "Journal of Fashion Marketing and Management", vol. 18(3), pp. 357-374, DOI: 10.1108/ JFMM-02-2013-0013.

Muncy J.A., Vitell S.J., 1992. Consumer ethics: An investigation of the ethical beliefs of the final consumer, "Journal of Business Research", vol. 24(4), pp. 297-311, DOI: 10.1016/0148-2963(92)90036-B.

Neale A., 2015, Zrównowažona konsumpcja. Źródła koncepcji i jej zastosowanie, „Prace geograficzne", z. 141, s. 141-158. 
Niinimaäki K., 2010, Eco-Clotbing. Consumer Identity and Ideology, "Sustainable Development", vol. 18, iss. 3, pp. 150-162, DOI: 10.1002/sd.455.

Pepper M., Jackson T., Uzzell D., 2009, An Examination of the Values that Motivate Socially conscious and Frugal Consumer Behaviours, "International Journal of Consumer Studies", vol. 33, iss. 2, pp. 126-136, DOI: 10.1111/j.1470-6431.2009. 00753.x.

Prahalad C.K., Ramaswamy V., 2000a, Dotaczanie kompetencii klienta, „Przegląd Organizacji”, $\mathrm{nr} 4$.

Prahalad C.K, Ramaswamy V., 2000b, Co-opting customer competence, „Harvard Business Review", no. 78(1), pp. 79-87.

Szmigin I., Carrigan M., O'Loughlin D., 2007, Integrating ethical brands into our consumption lives, "The Journal of Brand Management", vol. 14(5), pp. 396-409, DOI: 10.1057/palgrave.bm.2550084.

Sztucki T., 2001, Marketing w pytaniach $i$ odpowiedżiach, Agencja Wydawnicza Placet, Warszawa.

Tallontire A., Rentsendorj E., Blowfield M., 2001, Ethical Consumers and Ethical TRADE, "Natural Resources Institute. Policy Series", no. 12, http://www.nri. org/projects/publications/policyseries/PolicySeriesNo12.pdf [date of entry: 23.11.2018].

Włodarczyk-Śpiewak K., 2011, Nowoczesne technologie - wyžwanie dla wspótczesnych konsumentón, „Studies \& Proceedings of Polish Association for Knowledge Management", nr 51, s. 142-152.

www 1, http://twojrynek.pl [date of entry: 17.12.2018].

www 2, https://www.ekonsument.pl/a105_odpowiedzialna_konsumpcja.html [date of entry: 17.12.2018]. 